WSRC-TR $-91-403$

DE92 009534

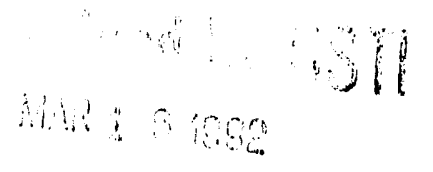

\title{
ENVIRONMENTAL TEST PROGRAM FOR SUPERCONDUCTING MATERIALS AND DEVICES: PRELIMINARY RESULTS OF TESTING PROGRAM AT SAVANNAH RIVER SITE (U)
}

by

H. W. Randolph, et al

Westinghouse Savannah River Company

Savannah River Site

Aiken, South Carolina 29808

This is a Technical Report

\section{DISCLAIMER}

This report was prepared as an account of work sponsored by an agency of the United States Government. Neither the United States Government nor any agency thureof, nor any of their employees, makes any warranty, express or implied, or assumes any legal liability or responsibility for the accuracy, completeness, or usefulness of any information, apparatus, product, or process disclosed, or represents that its use would not infringe privately owned rights. Reference herein to any specific commercial product, process, or service by trade name, trademark, manufaciurer, or otherwise does not necessarily constitute or imply its endorsement, recommendation, or favoring by the United States Government or any agency thereof. The views and opinions of authors expressed herein do not necessarily state or reflect those of the United States Government or any agency thereof.
\end{abstract}

This paper was prepared in connection with work done under Contract No. DE-AC09-89SR18035 with the U.S. Department of Energy. By acceptance of this paper, the publisher and/or recipient acknowledges the U.S. Government's right to retain a nonexclusive, royalty-free license in and to any copyright covering th $\mathrm{s}$ paper, along with the right to reproduce and to authorize others to reproduce all or part of the copyrighted paper. 


\begin{abstract}
Interim Report
ENVIRONMENTAL TEST PROGRAM FOR SUPERCONDUCTING MATERIALS AND DEVICES
\end{abstract}

\author{
Preliminary Results of Testing Program at SRS \\ to \\ Dr. Gene Haertling \\ Ceramic Engineering \\ Clemson University \\ Clemson, SC 29634
}

Investigators:

Henry Randolph - Westinghouse Savannah River Co.

Darren Verebelyi - Westinghouse Savannah River Co.

- Clemson University

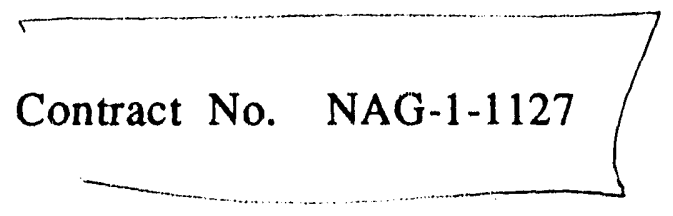

May 30, 1991 


\section{Introduction}

The properties of $\mathrm{YBa}_{2} \mathrm{Cu}_{3} \mathrm{O}_{7-x}$ superconducting tapes designed and fabricated into SAFIPE-type, encapsulated, grounding links by the Ceramic Engineering Department at Clemson University are under investigation(NASA Contract No. NAG-1-1127). Testing at the Savannah River Site will include gamma irradiation, vibration, and long-term evaluation. The gamma irradiation portion of testing has been completed. The long-term testing began in January and will continue. The vibration test has yet to be started.

\section{Radiation Test}

Eight samples were irradiated in a high level gamma well. These samples were recisived from Clemson with known resistance vs. temperature curves. Before irradiation the samples were videotaped with the full screen of a monitor equaling the width of the sample. The samples were then immersed in liquid nitrogen and exposed to ${ }^{137} \mathrm{Cs}$ for 126 total hours hours over a 10 day period. The main energy peak of the ${ }^{137} \mathrm{Cs}$ spectrum is at $661.66 \mathrm{keV}$. The calibrated exposure rate was $96.940 \mathrm{R} / \mathrm{hr}$ as shown in Table 1. The equivalent gamma radiation dose in water is equal to $11,000 \mathrm{rad}$. The cross section for gamma absorption in 123 material is greater than water so this dose would be a lower limit.

After irradiation these samples were videotaped again in the same manner as before exposure. The only physical change resulting from the treatment was minor epoxy liftoff from the 123 material. This has also been observed at Clemson on some samples during long periods of liquid nitrogen immersion. The samples were returned to Clemson for comparison resistance vs. temperature curves. 


\section{Long-Term Test}

The long-term test is monitoring for decomposition by-products and changes in resistance while maintaining low temperature(77K) and high vacuum(10-7 torr). The equipment to perform measurements includes a cryostat and a vacuum system consisting of stainless steel piping configured to accommodate two, 20-pin, electronic signal feedthroughs, an ion pump, and a mass spectrometer head. The cryostat is immersed in liquid nitrogen from a 50 liter dewar. Liquid nitrogen is replenished to the 50 liter dewar by an interchangeable 160 liter dewar.

Continuous data acquisition by computer control compiles measurements of current, voltage, temperature, pressure, and partial pressure. Data are taken on 15 minute intervals and written into two text files along with a date and time stamp. Measurements are taken by a Hewlett Packard 3457A Multimeter, Hewlett Packard Scanner, and Dycor Quadrupole Mass Spectrometer. The multimeter was certified and is NIST traceable.

Voltage and current measurements are written to disk and resistance is calculated from Ohm's law. Temperature is calculated from the resistance measurement of a calibrated ceramic RTD. Pressure is calculated from a voltage measurement on the ion pump controller. Partial pressures of 12 masses are normalized to the ion pump pressure in torr.

A current of $10 \mathrm{ma}$ was applied to all eight samples for the first week, then the current was removed from four samples for the balance of the test. Samples were arranged in two groups of four as given in Table 2. The one inch diameter cryostat holds the samples as shown in Figure 1. This orientation allows the temperature measurement to be an upper limit. The continuous current samples are at a lower temperature due to their position at the bottom of the cryostat. The thermal transfer of the tube produces a temperature 
gradient of approximately $7 \mathrm{~K}$ from the bottom of the cryostat to the ceramic RTD.

\section{Results}

The long term test portion of the program has been in progress for more than 3000 hours. Data were collected each minute during the initial cooling of the samples on 15 Jan 91. Data from sample number 212 were omitted due to its failure to go superconducting after its initial testing on 21 Dec 90 . These data were plotted as resistance vs. temperature for each sample and are given in Figures 2,3 , and 4 . The pressure during the superconducting transition changed for an unexplained reason, with an increase in pressure from $1 \mathrm{E}-5$ to $5 \mathrm{E}-2$ torr. The transition temperature is defined as the point in which the resistance is 10 milliohms. The seven samples all exhibited transitions at approximately $79 \mathrm{~K}$. This transition temperature is $9 \mathrm{~K}$ below a similar curve, shown in Figure 5, which was taken at Clemson. Curves from similar samples tested at SRS in the past have shown transitions at about $89 \mathrm{~K}$. A typical example is given in Figure 6.

Resistance data for the three constant current samples are graphed in Figures 7-15. The three samples produced data that were very consistent. The only anomaly was during the first 700 hours of sample number 204. Shortly after the initial cooling of sample number 204, a negative potential of approximately 5 microvolts was recorded. This effect disappeared 700 hours later during a rection of data loss. Raw data are missing for various reasons and the corresponding times are recorded in Table 3. The current supply was interrupted only once. This 24 hour period on $27 \mathrm{Feb} 91$ was due to a power outage.

Degradation evaluation of 123 material is of prime importance in the long-term portion of testing. Analysis of degradation of the samples was done by using six data sets each 10 hours in length. These sets are chosen at stable sections of the data at 
approximately $84 \mathrm{~K}$. Figure 16 shows the average resistance divided by the average temperature for the six ranges. The resistance range of 200-400 microhms is comparable to the lead and contact resistance expected. The fact that these values do not increase is an indication that there is no degradation of the 123 material's superconducting properties.

Data for pressure and temperature of the system are also graphed in Figures $17,18, \& 19$. Pressure is presently less than $8 E-8$ torr. This is down from a typical $3 E-7$ torr in February. Partial pressure data plotted for. particular masses of interest are given in Figure 20. The decrease in pressure over time is normal and is due to the continuous pumping of surface sorbed gases. The ratios change as material is removed from surfaces at different rates.

\section{Continuing work}

Data will continue to be obtained and is expected to show a continuing decrease in water content of the vacuum system and a slow decline in hydrogen pressure. Full scans of all masses will. be taken periodically and compared to data with the isolation valve closed so an assessment of any by-products from decomposition can be analyzed. The vibration test will be performed when equipment becomes available. 


\section{TABLE 1}

\section{GAMMA WELL CALIBRATION}

SRL EXPERIMENT - March 1991

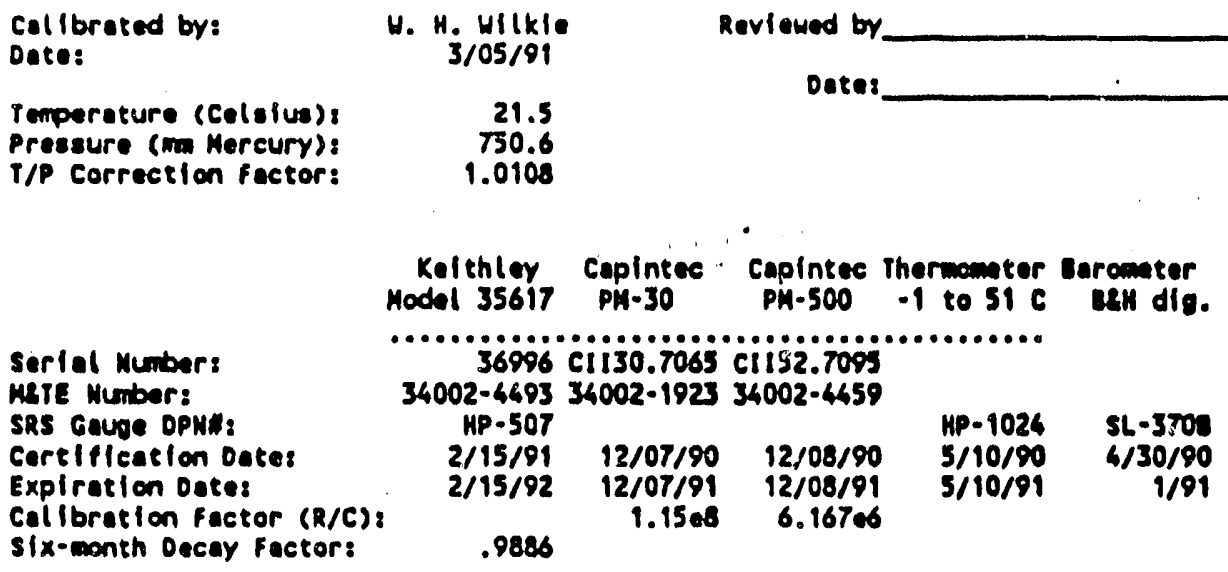

SHIELD OPEN -. 2.75 INCHES ABOVE LUCITE TROLLEY

Woll setting (ft)

Exposure Rate $(\mathrm{ma} / \mathrm{h})$

Hell setting

(ft)
.35
.35
.35

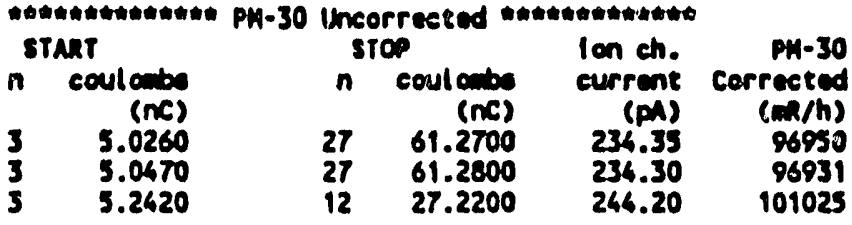

Inside dewer Inalde dewer outslde 
TABLE 2

SAMPLE TYPE* CURRENT

$\begin{array}{llll}\text { GROUP 1: } & 203 & \text { TAB } & \text { YES } \\ & 204 & \text { TAB } & \text { YES } \\ & 212 & \text { PIN } & \text { YES } \\ & 213 & \text { PIN } & \text { YES } \\ \text { GROUP 2: } & 232 & \text { TAB } & \text { NO } \\ & 209 & \text { TAB } & \text { NO } \\ & 214 & \text { PIN } & \text { NO } \\ & 217 & \text { PIN } & \text { NO }\end{array}$

* $\quad \mathrm{TAB}=$ Silver foil tab

PIN = Gold plated pin 
TABLE 3

MISSING DATA SEGMENTS

$\begin{array}{rccc}\text { DATE } & \text { START } & \text { STOP } & \text { HOUR } \\ 15 \text { Feb } & 8: 55 & & 737 \\ 19 \mathrm{Feb} & & 9: 10 & 834 \\ 27 \mathrm{Feb} & 18: 52 & & 1036 \\ 28 \mathrm{Feb} & & 19: 07 & 1055 \\ 8 \mathrm{Mar} & 19: 06 & & 1259 \\ 11 \mathrm{Mar} & : & 16: 14 & 1328 \\ 12 \mathrm{Apr} & 7: 36 & & 2089 \\ 13 \mathrm{Apr} & & 7: 12 & 2112 \\ 25 \mathrm{Apr} & 12: 45 & & 2406 \\ 1 \mathrm{May} & & 0: 45 & 2539\end{array}$




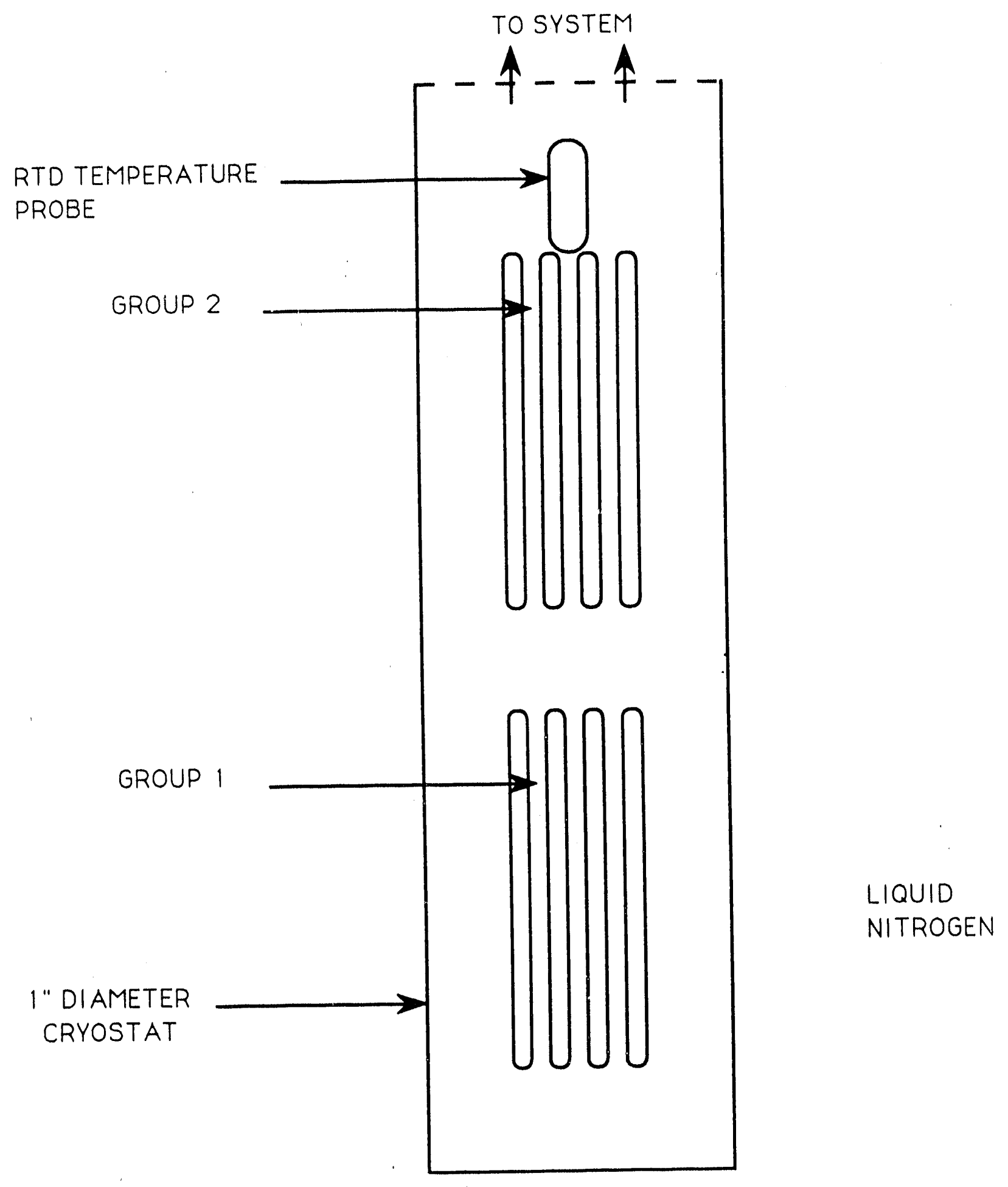

FIGURE I SCHEMATIC ORIENTATION OF SAMPLES IN CRYOSTAT 

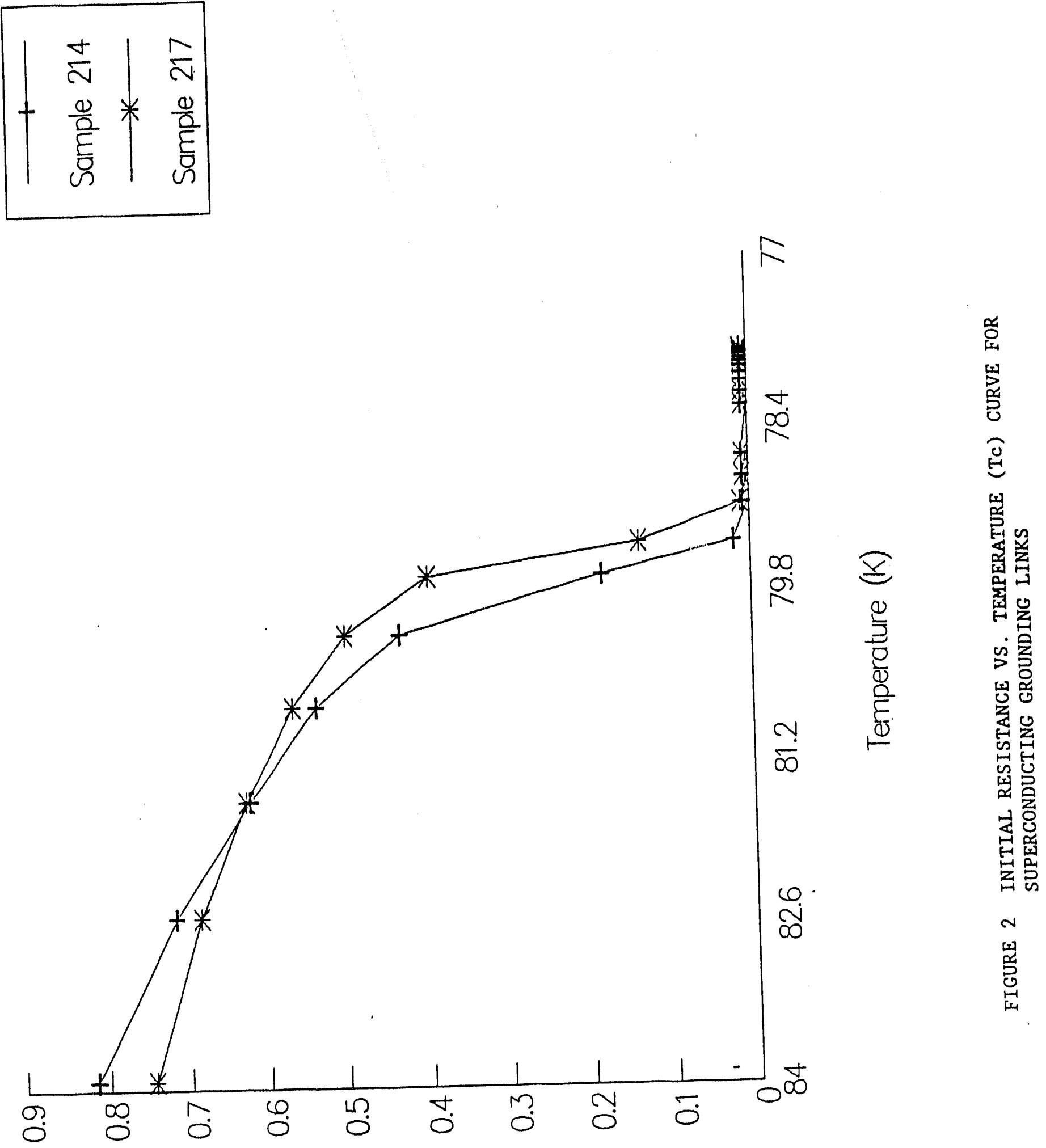

(smyo) asudjs!say 

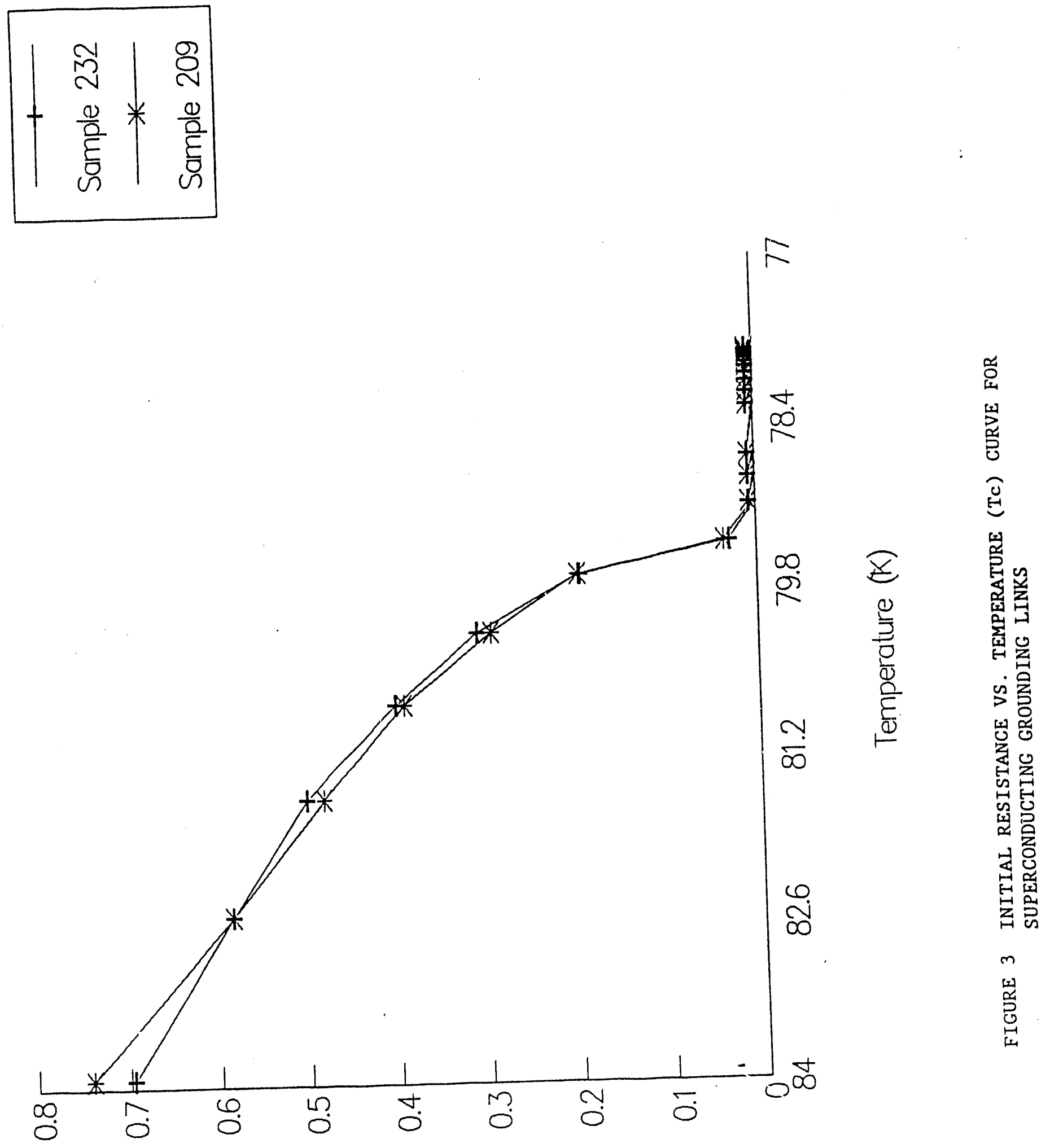

(su40) әJuplsisay 

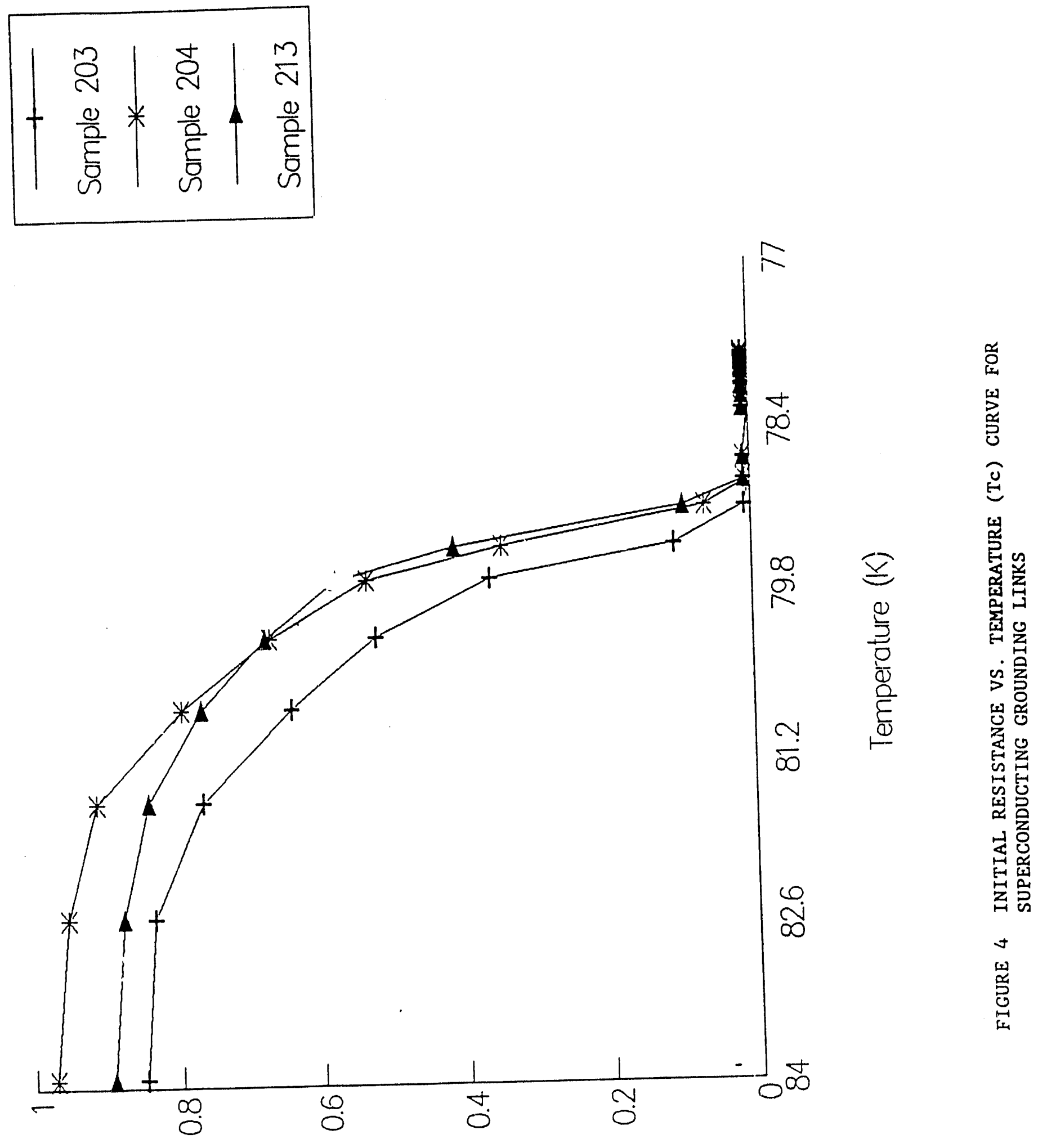

(sinuo) әOudisisad 


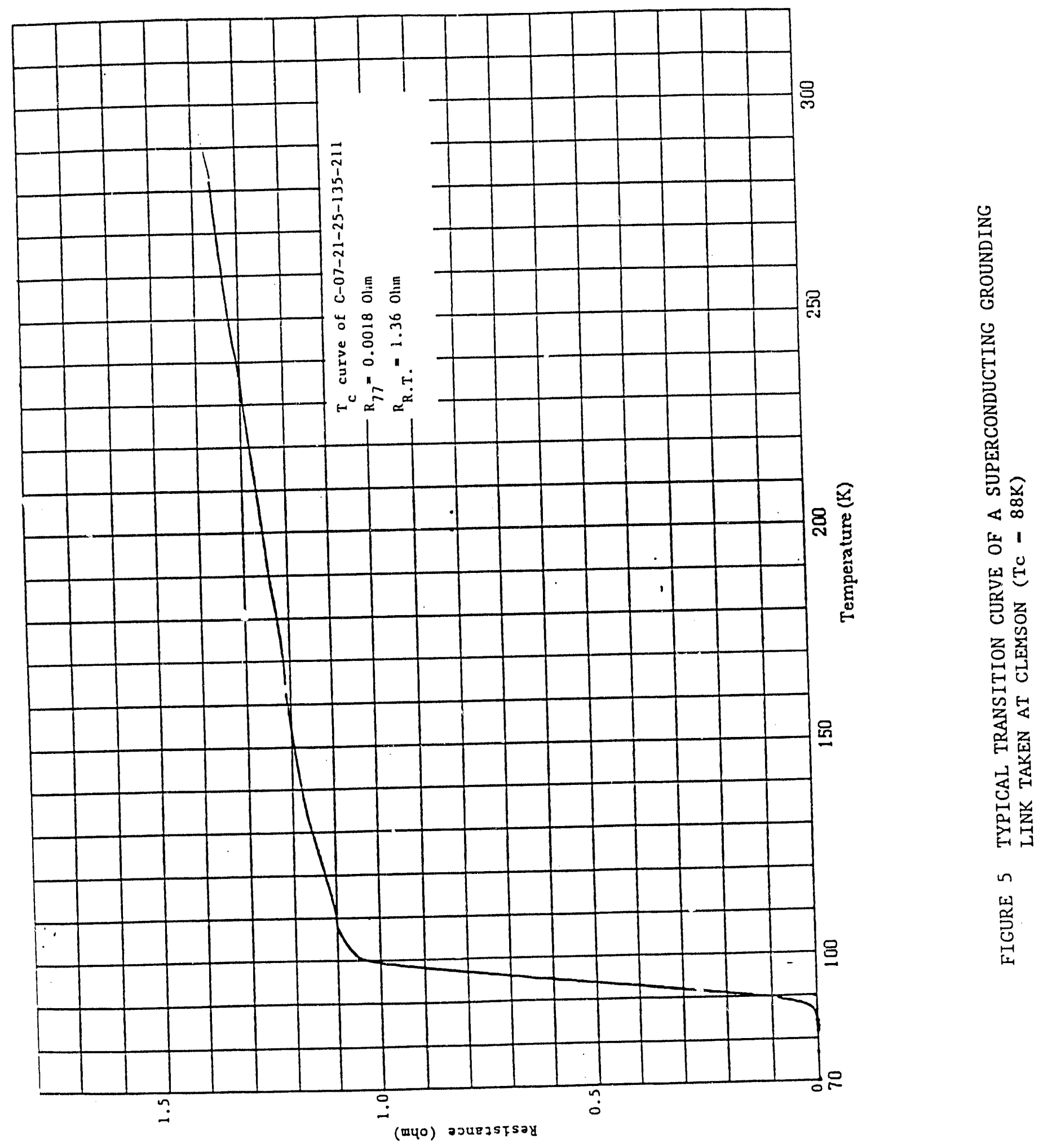



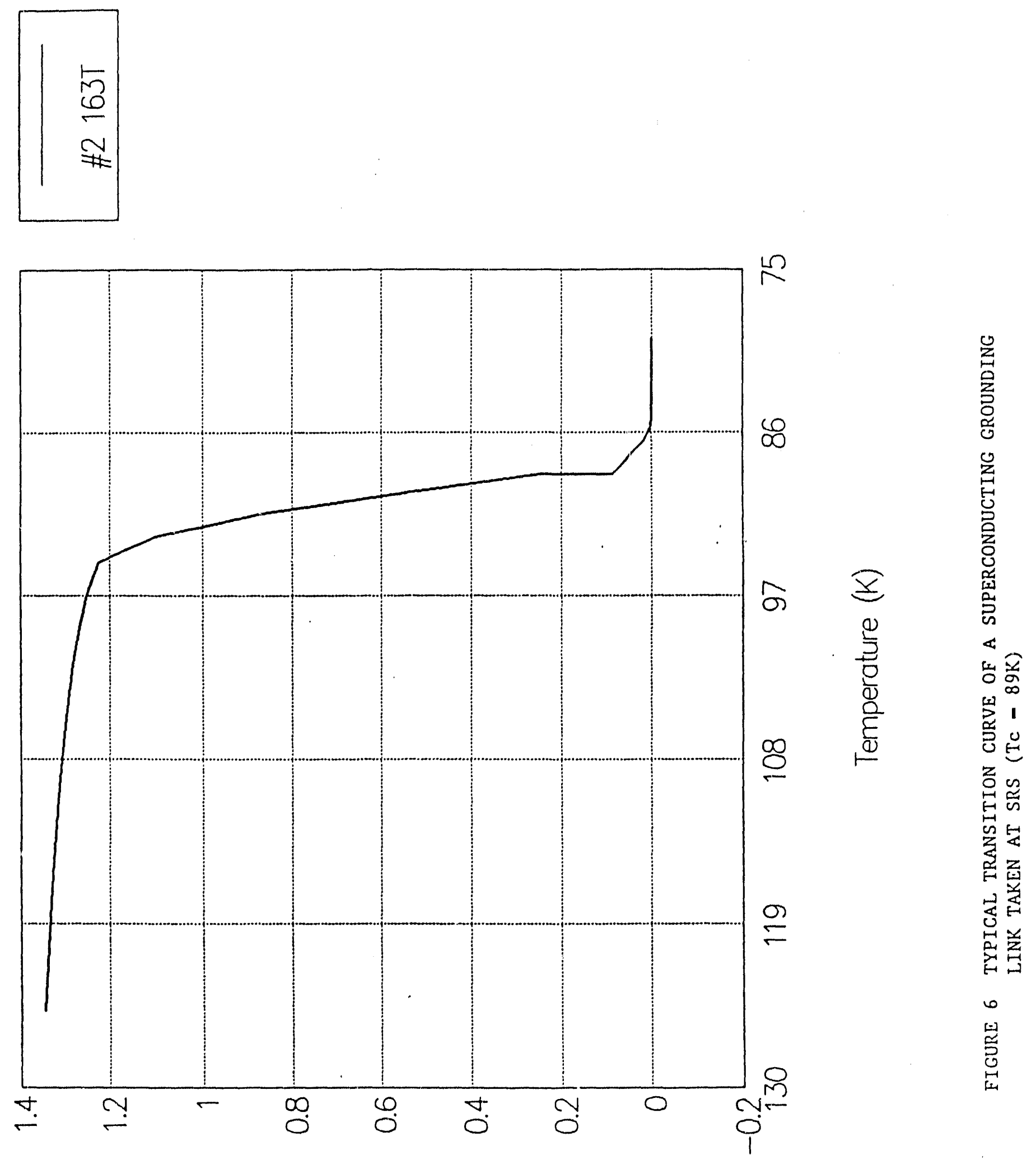

(suyo) ajudis!say 


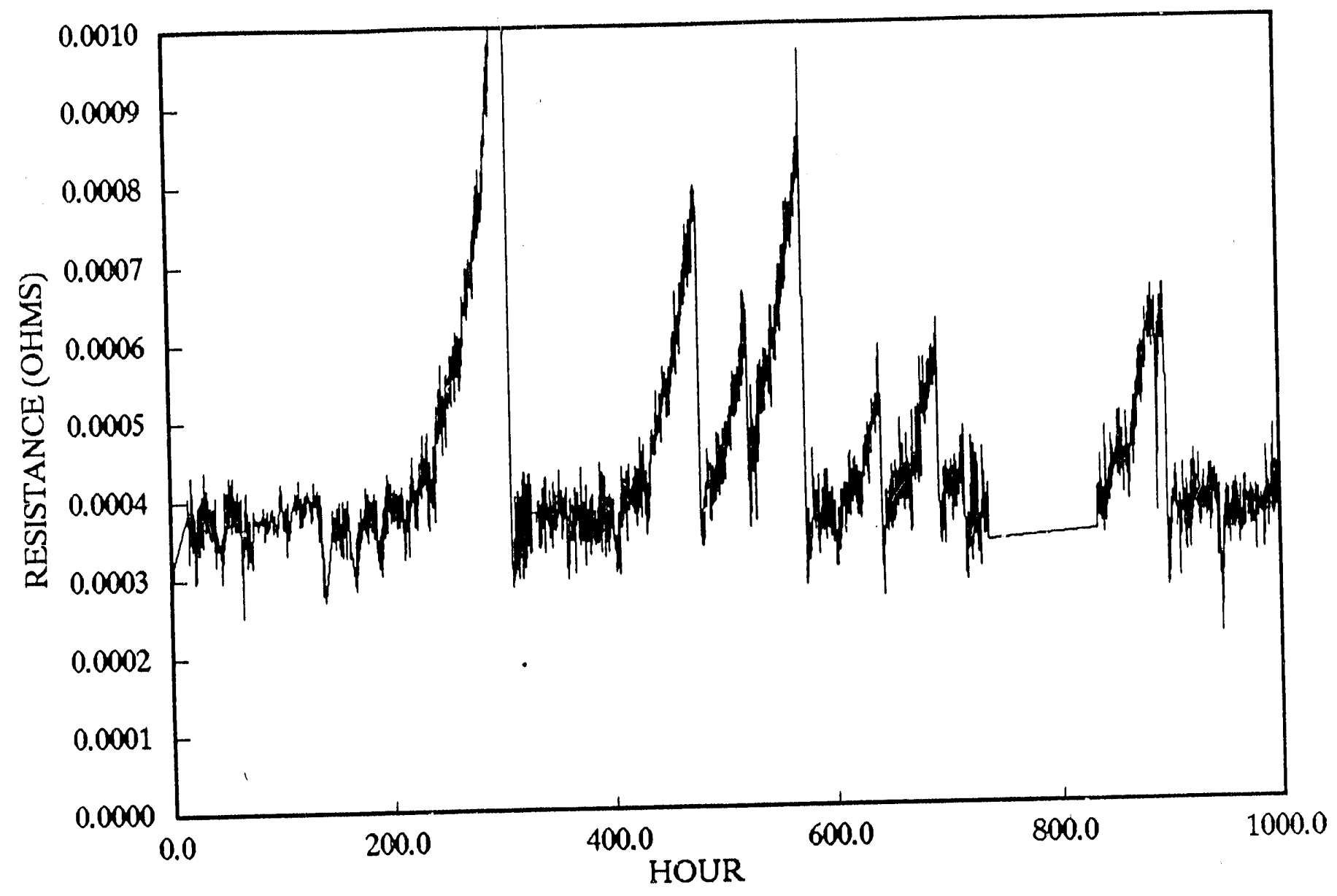

FIGURE 7 RESISTANCE VS. HOURS FOR SAMPLE 203 O-1000 HOURS 

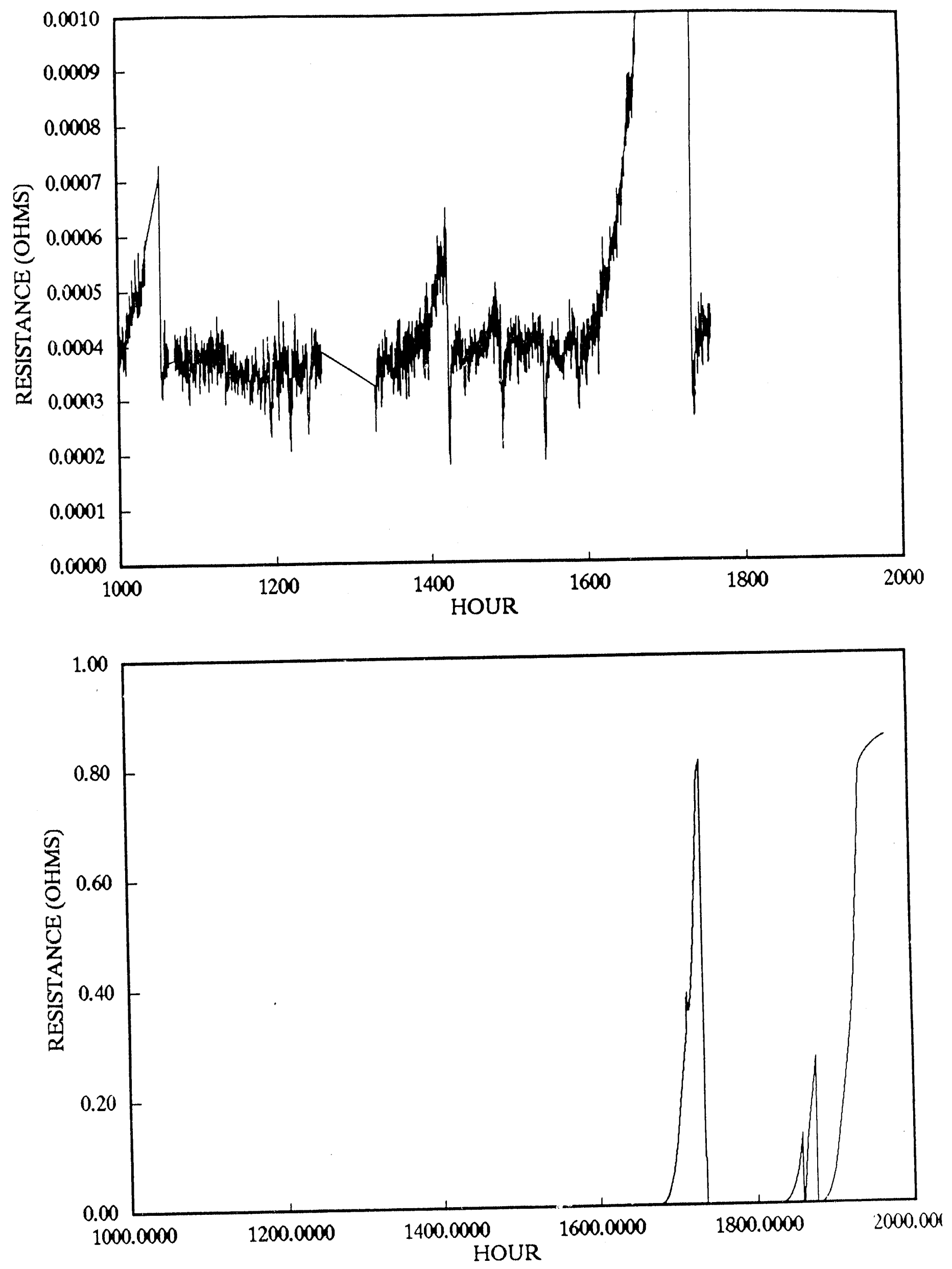

FIGURE 8 RESISTANCE VS. HOURS FOR SAMPLE 203 1000-2000 HOURS 


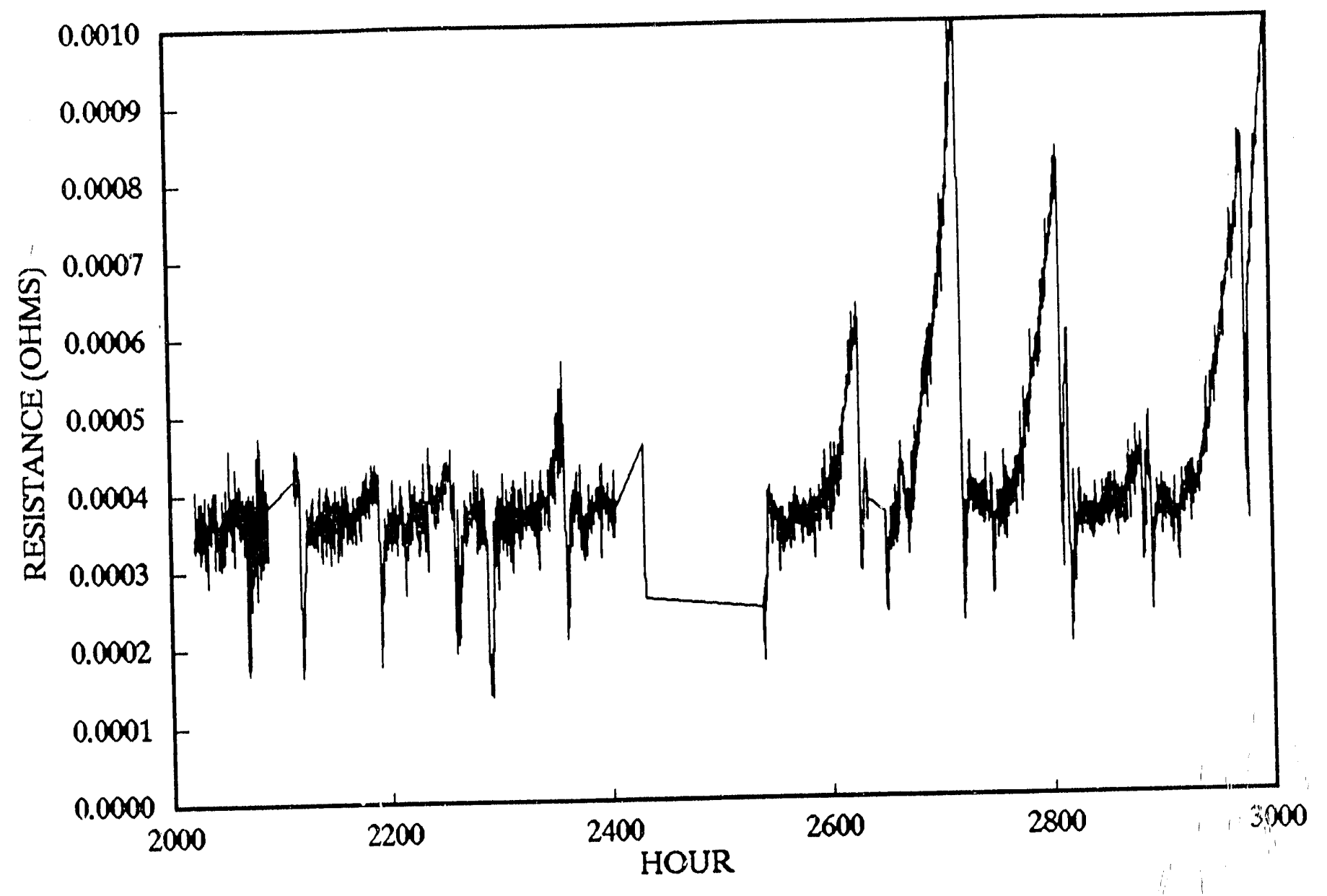

$\begin{array}{ll}\text { EIGURE } 9 & \text { RESISTANCE VS. HOURS FOR SAMPLE } 203 \\ & 2000-3000 \text { HOURS }\end{array}$ 


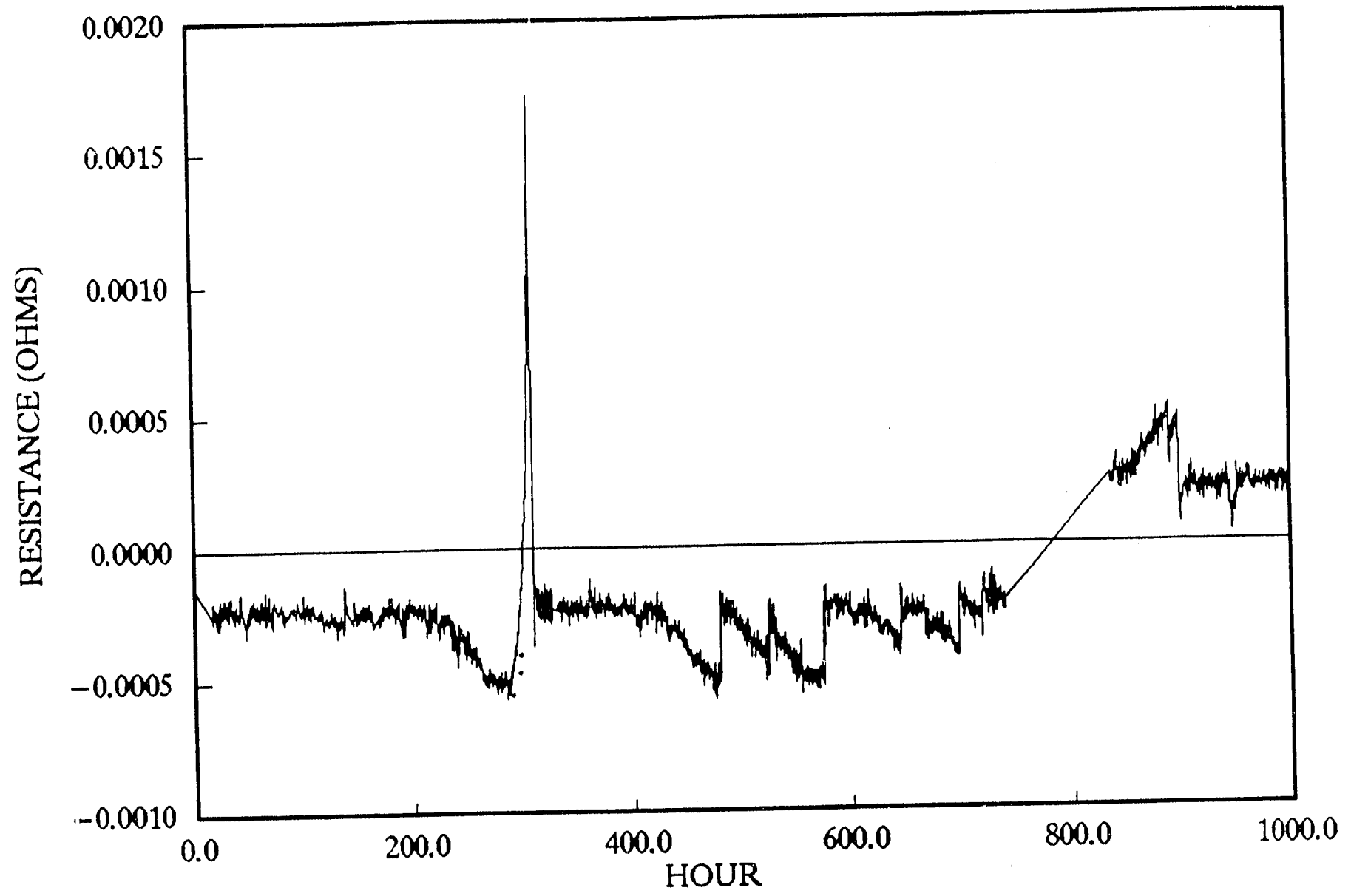

FIGURE 10 RESISTANCE VS. HOURS FOR SAMPLE 204 0-1000 HOURS 

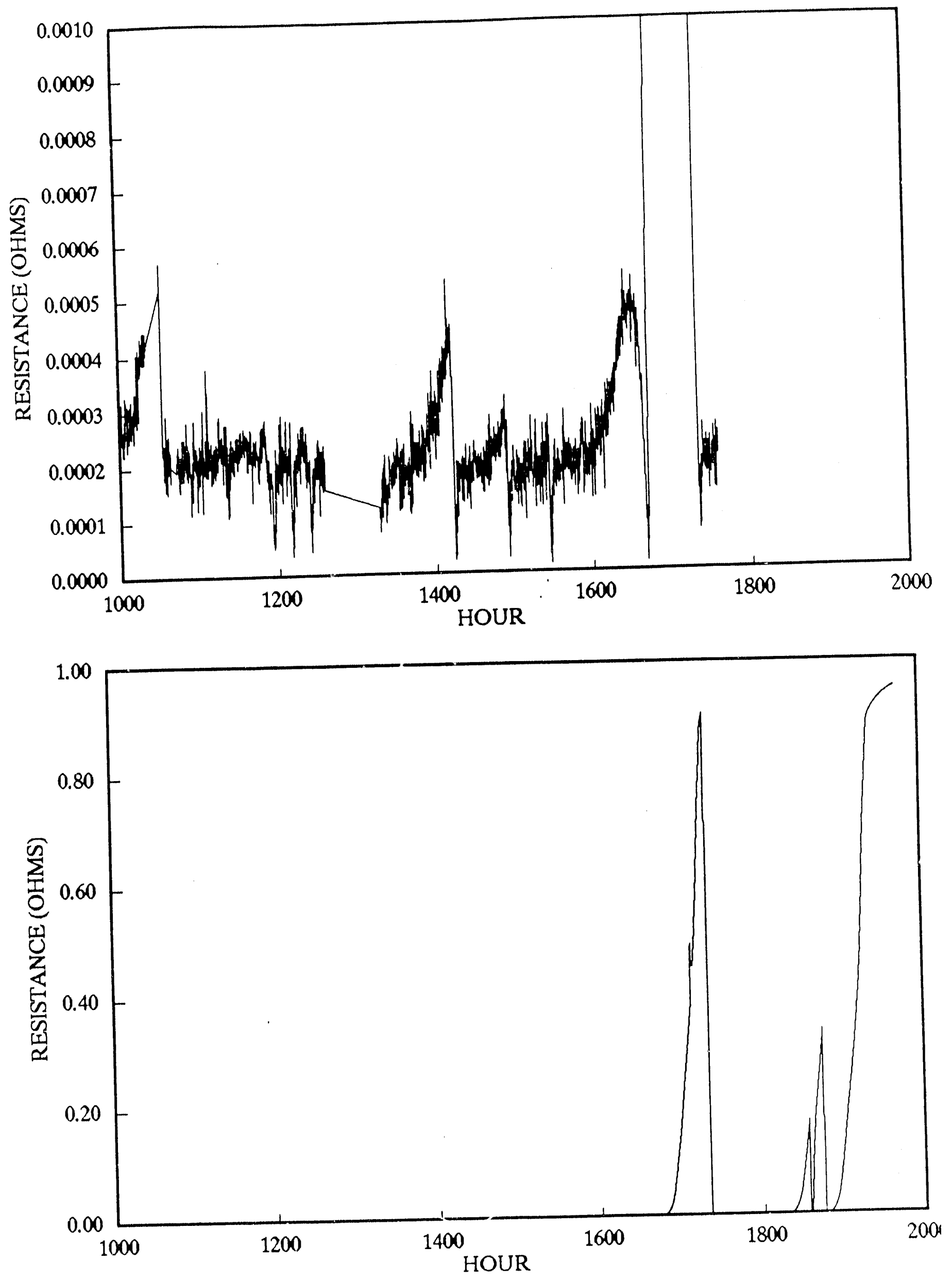

FIGURE 11 RESISTANCE VS. HOURS FOR SAMPLE 204
$1000-2000$ HOURS 


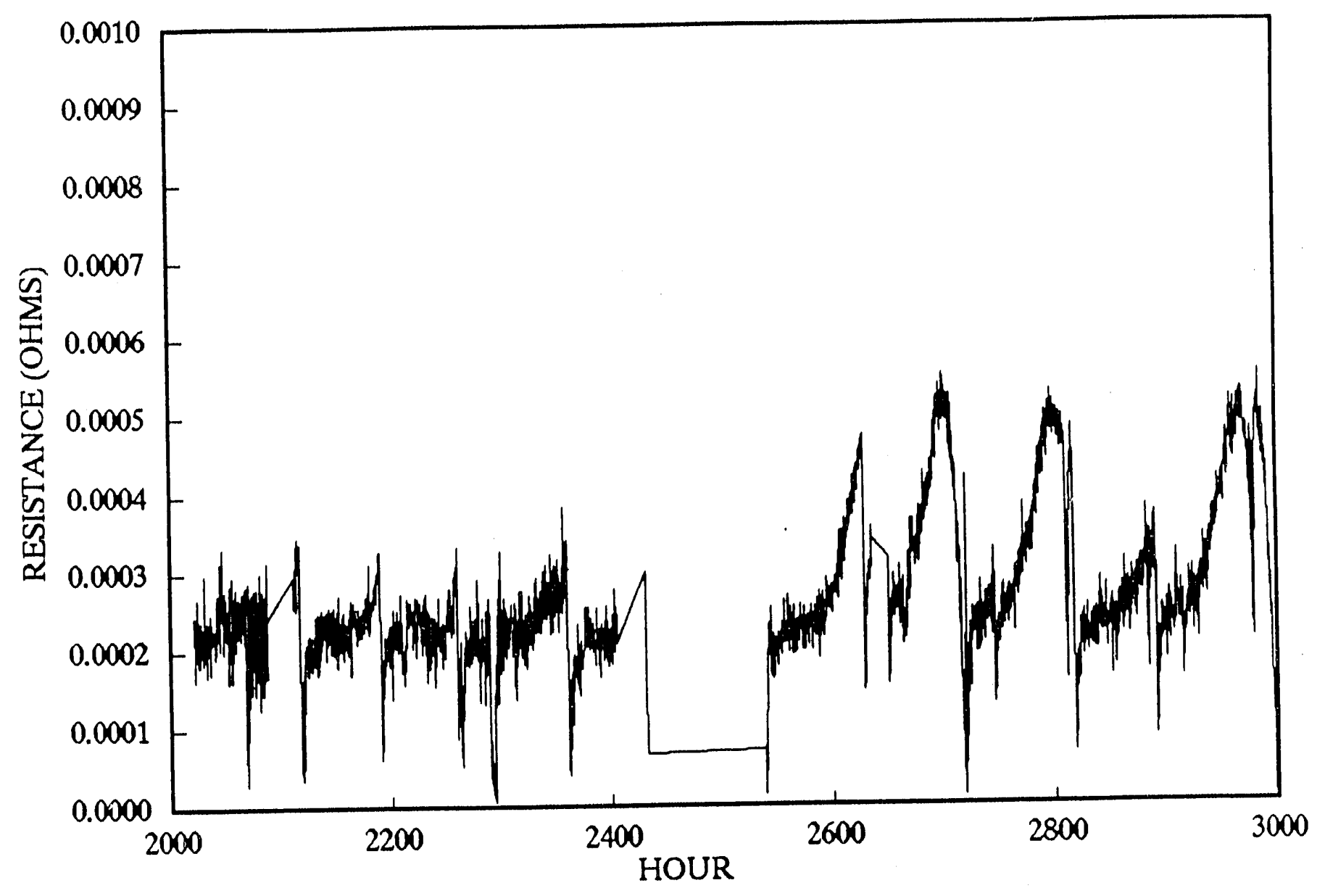

FIGURE 12 RESISTANCE VS. HOURS FOR SAMPLE 204 2000-3000 HOURS 




FIGURE 13 RESISTANCE VS. HOURS FOR SAMPLE 213 O-1000 HOURS 

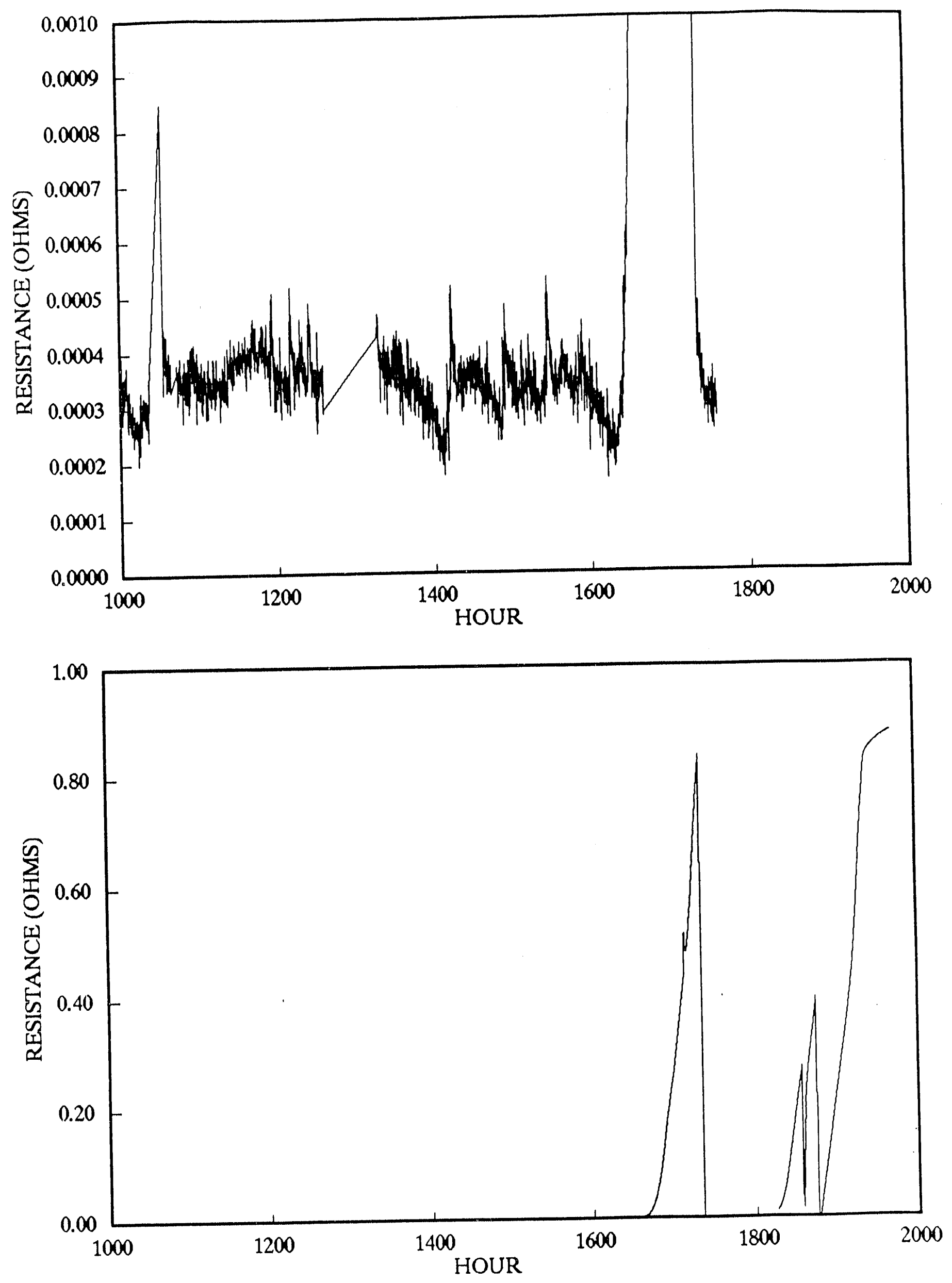

FIGURE 14 RESISTANCE VS. HOURS FOR SAMPLE 213 1000-2000 HOURS 


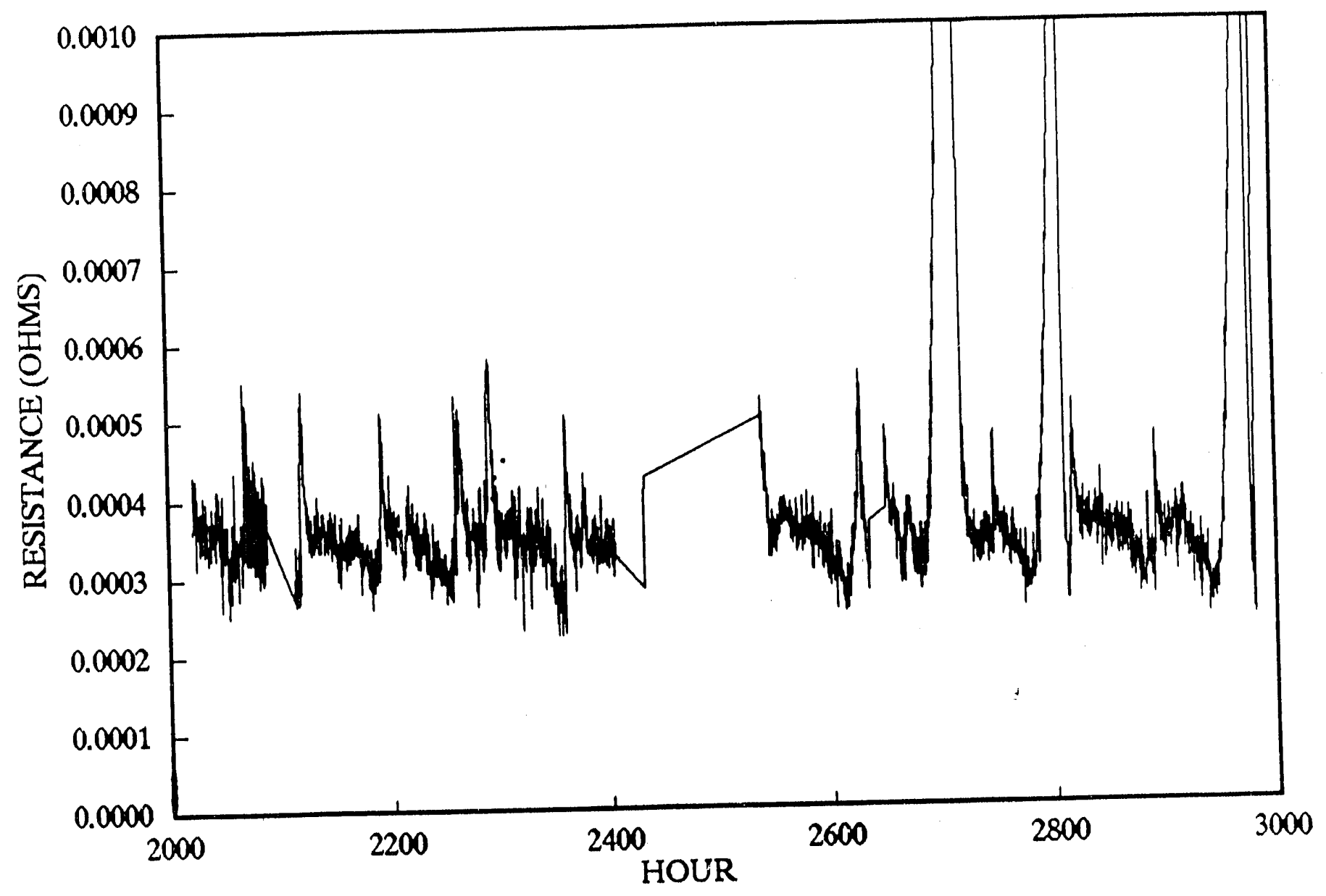

FIGURE 15 RESISTANCE VS. HOURS FOR SAMPLE 213 2000-3000 ROURS 


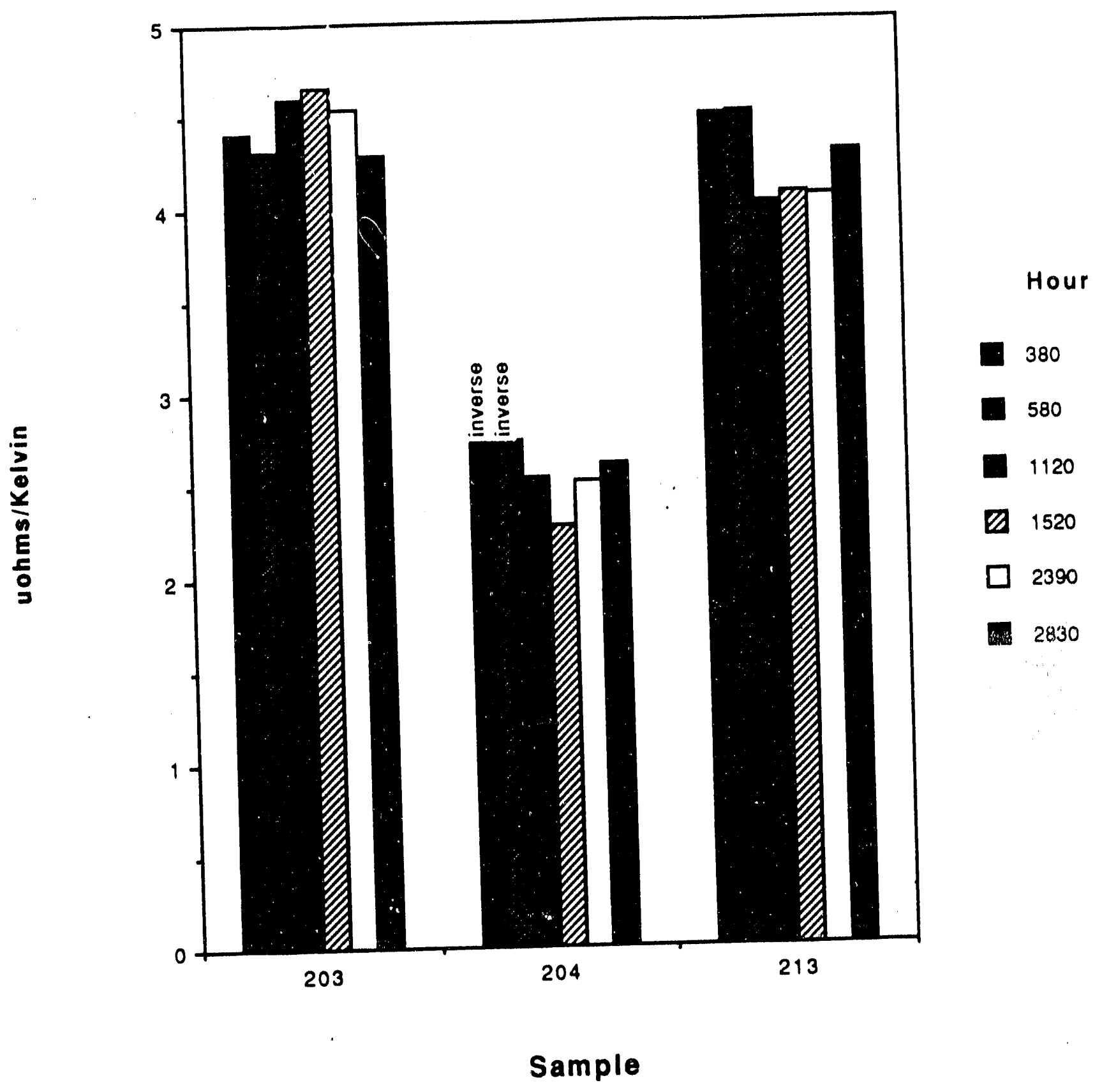

FIGURE 16123 MATERIAL DEGACATION CHECK OF SAMPLES 203, 204, AND 213. 


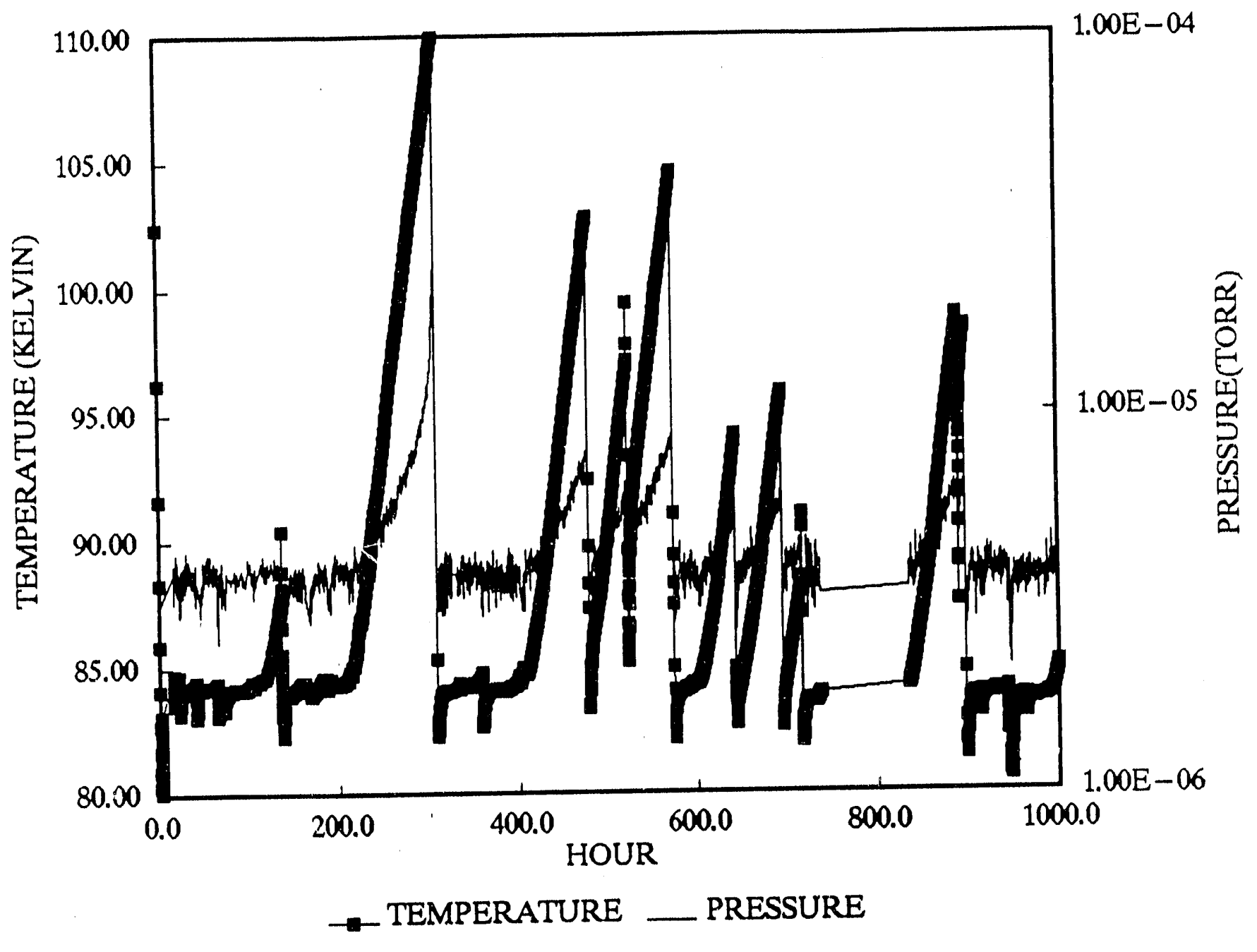

FIGURE 17 TEMPERATURE AND SYSTEM PRESSURE VS. HOURS O-1000 HOURS 


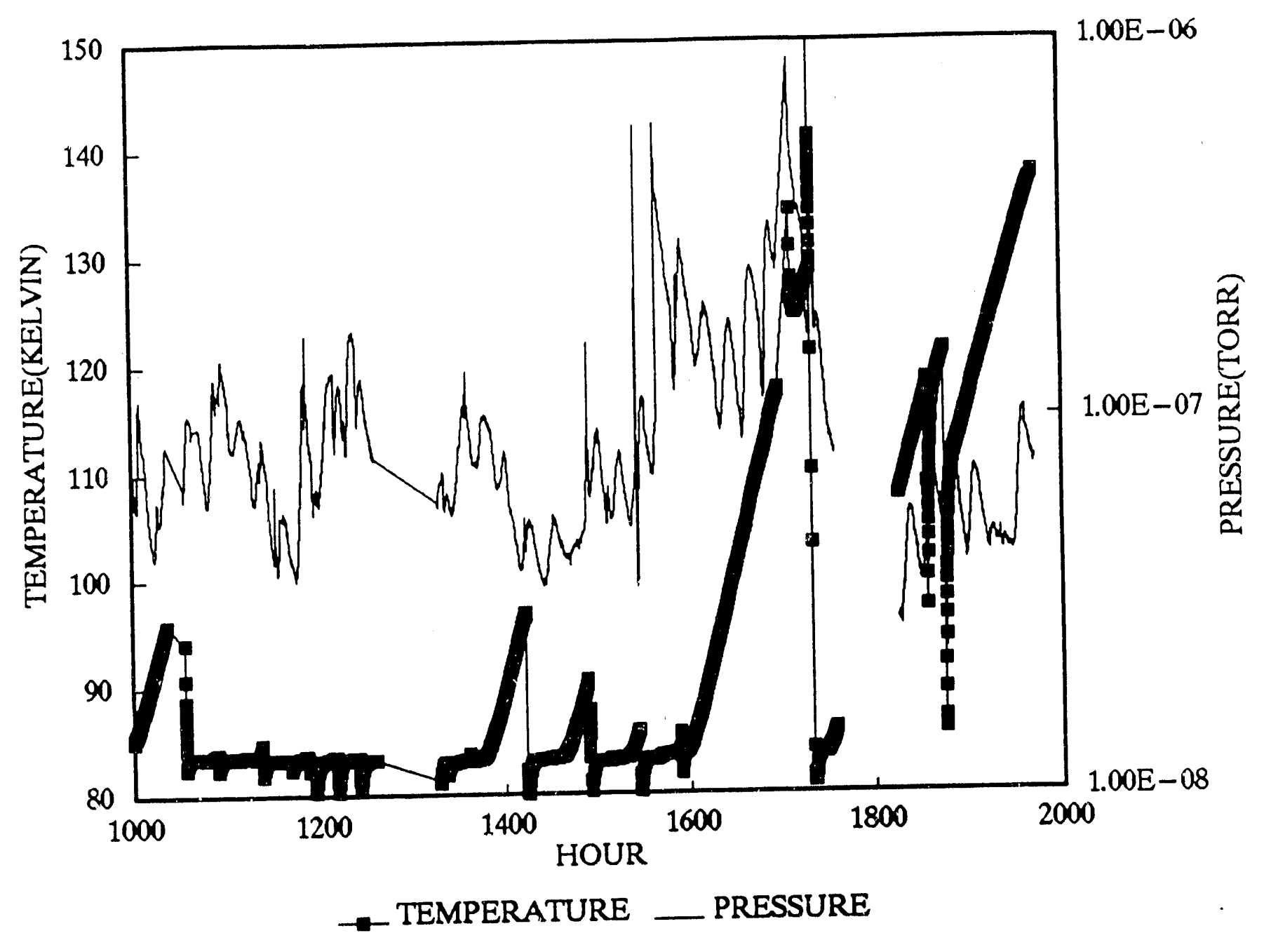

FIGURE 18 TEMPERATURE AND SYSTEM PRESSURE VS. HOURS 1000-2000 HOURS 


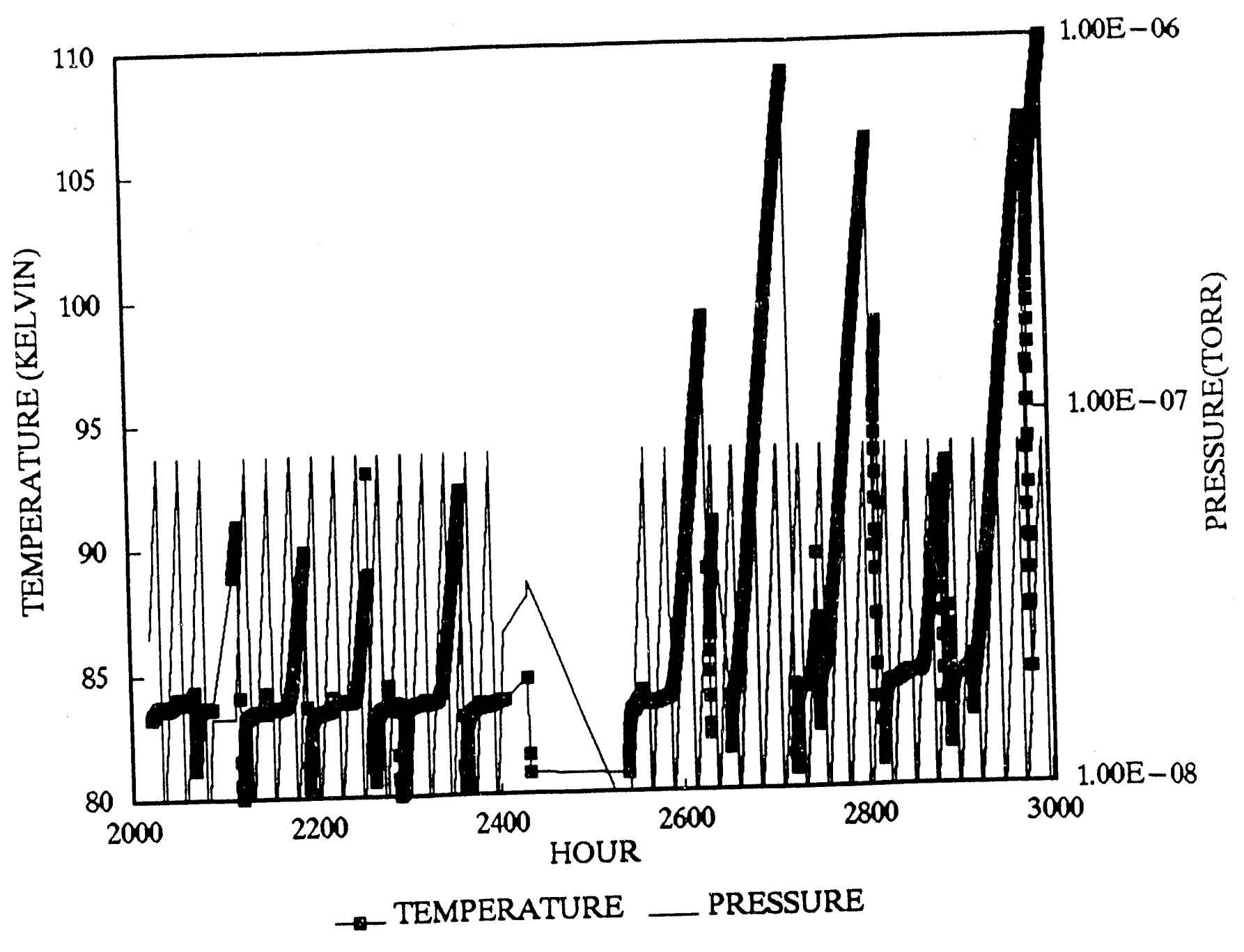

FIGURE 19 TEMPERATURE AND SYSTEM PRESSURE VS. HOURS
$2000-3000$ HOURS 


$$
\text { Whu }
$$



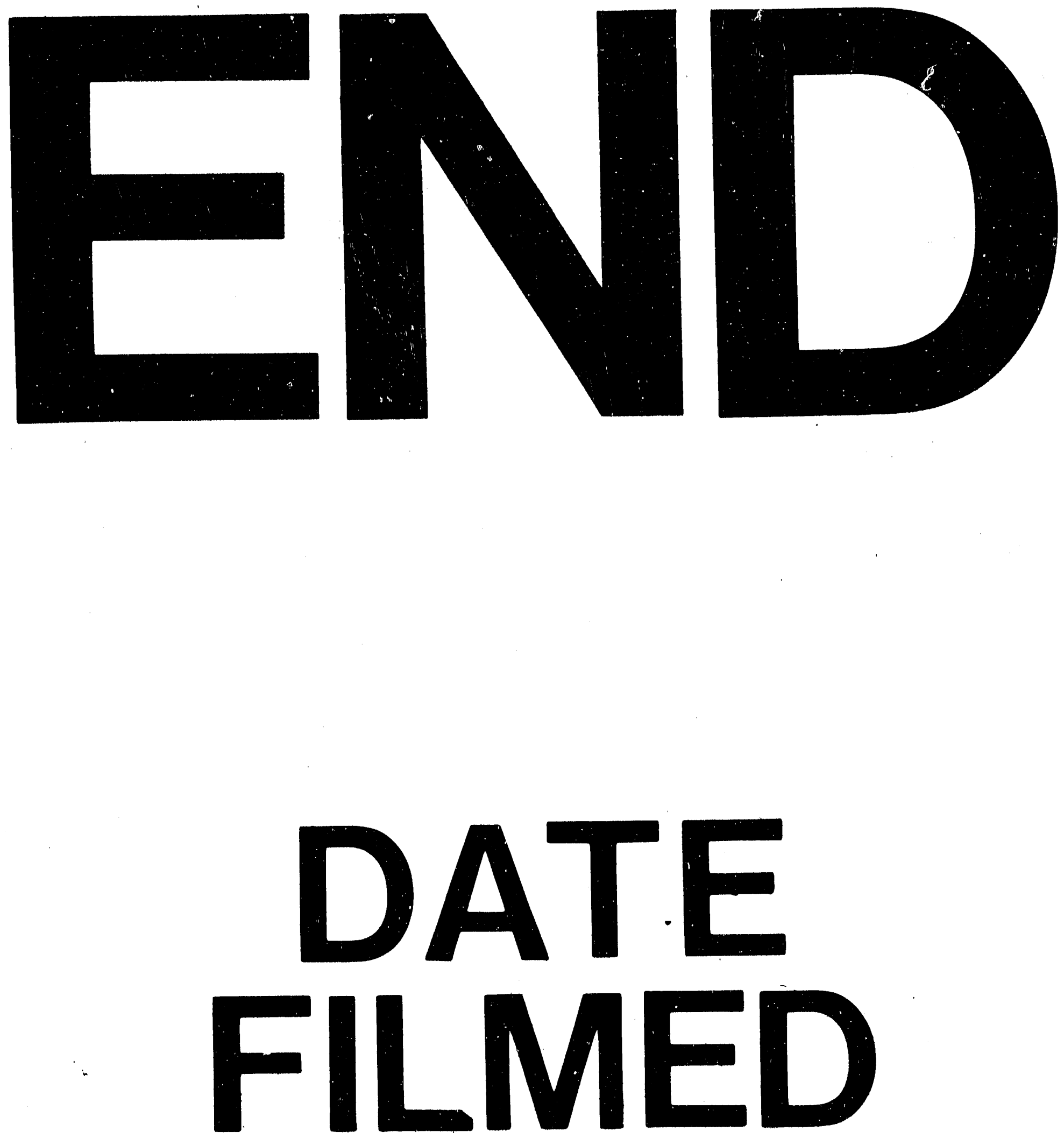

7

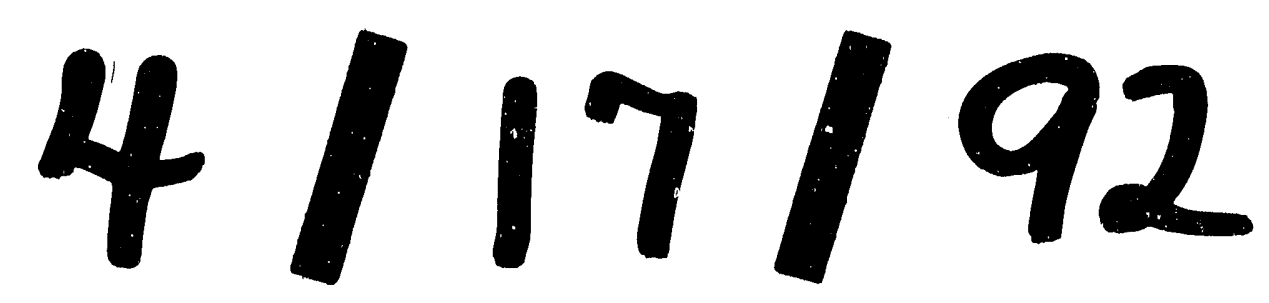


